\title{
Impact of Stone Enzyme Wash and Acid Wash Based on Denim Garments
}

\author{
Tahmina Jahan*, Jahid Khan \\ Department of Textile Engineering, Bangladesh University of Business and Technology (BUBT), Dhaka, Bangladesh \\ Email: *tahminaakhi41@gmail.com, jahidkhan1995.jk@gmail.com
}

How to cite this paper: Jahan, T. and Khan, J. (2022) Impact of Stone Enzyme Wash and Acid Wash Based on Denim Garments. Journal of Textile Science and Technology, 8, 43-57. https://doi.org/10.4236/jtst.2022.81005

Received: September 22, 2021

Accepted: February 8, 2022

Published: February 11, 2022

Copyright ( 2022 by author(s) and Scientific Research Publishing Inc. This work is licensed under the Creative Commons Attribution International License (CC BY 4.0).

http://creativecommons.org/licenses/by/4.0/

(c) (i) Open Access

\begin{abstract}
The aim of this project is to find out the changes that occur in physical properties of denim when it is subjected to enzyme stone and acid wash or to find out the impact of enzyme stone and acid wash. 97\% cotton 3\% elastomer twill, weave $3 / 1$, construction $72 \times 40 / 9 \times 7$ indigo dyed denim fabric leg panels as per lab standard recipe are used here to examine. Firstly, desizing was done as pre-treatments and after treatment was silicon softener. After washing process, different samples from both washing are going to express different behavior on physical properties. This experiment is done to find out the discrimination in tearing strength, shrinkage \%, color fastness to wash, color fastness to rubbing, $\mathrm{pH}$ rate between stone enzyme wash and acid wash of denim garments.
\end{abstract}

\section{Keywords}

Stone Enzyme Wash, Acid Wash pH Range 4.5 - 5.5, Shrinkage \%, Tearing Strength, Color Fastness

\section{Introduction}

Denim clothes have a lot of demand in the market of regular clothes as well as in the fashion market. People of all ages, especially the youth have a great interest in the denim [1]. Different value-adding processes like industrial washing make the denim not only look beautiful but also impart some functional properties to the cloths. Already made cloths from solid color, from dyed or pigment printed fabrics, the clothes are washed by different clothe washing techniques [2]. Thus color, outlook and comfortability of the clothes are modified. As a result, a new outlook and appearance are produced in the clothes, which is not possible in any other method. Moreover, starch present in the cloths is removed by the washing. Moreover washed clothes could be worn after purchase directly from the store or 
shop. Some clothes shrink after wash, hence washed clothes could be purchased as per required size without consideration of further shrinkage [3].

Among different techniques of cloths washing, enzyme is chosen to fade color from all over the cloths in a regular manner and to polish the surface of the fabric [4]. In stone washing, denim cloth is washed along with pumice stone in industrial washing machine. During washing, the denim and pumice stones are spun together in the washing machine and produce better distressed look. To minimize the unwanted wear and tear of the cloths due to the presence of pumice stone in the wash bath, the washing conditions should be set correctly and carefully [5].

Using pumice stone causes wear and tear of the cloths and the machine surface. Enzymatic treatments have a lot of advantages over stone washing but the stone has a different irregular effect on the cloths which is very difficult to achieve with only enzyme [6]. As only stone causes harm to the cloths and machine, then using enzyme with the stone can bring the desired effect quickly with minimum harm to the cloths and machine. So, using enzyme and stone both in the same bath helps to achieve the required shade in a comparatively short time with wear and tear of the cloths within a tolerable range [7].

During Acid wash, pumic stones are used. By the action of pumic stones, an irregular fading effect is developed on heavy clothes like denim, thick canvas/twill, and sweater [8]. The pumic stones act as a brushing action on the cloth fabric surface. The area where more brushing action takes place there more discolor or fading effect is developed and the area where less brushing action takes place less brushing action and takes place less fading effect will be developed. The multi-layer fabric areas like collar, calf, pocket, placket, side seam, etc., area will be brushed more than the single layer areas. As a result, a irregular fading effect will be developed on the clothes fabric surface. Thus in this way, a fading effect may be developed on the cloth by acid wash technique [9].

This paper investigates the impact of enzyme-pumice stone wash on the physical and mechanical properties of denim cloths as these properties determine the wearers' feel and life of the end product [10]. The minimum loss in the strength and fabric weight is preferable as well as other functional properties should be unharmed or should improve. Besides, the outlook of the clothes should be as per the demand. Meeting these parameters at an acceptable point is a very difficult task but better and optimum process control in enzyme-stone washing can solve that [11].

\section{Materials and Method}

To perform a successful experiment the following materials, instructions and methods are used in this project.

\subsection{Raw Materials}

$97 \%$ cotton and 3\% elastane denim fabric were used. These comprised bluish 
denim fabric, GSM 358, 3/1 warp faced S-twill, construction $72 \times 40 / 9 \times 7$, fabric width 57 inch. Then sewn 2 leg panel.

\subsection{Working Place}

Washing Laboratory Departmental Pacific Jeans Ltd., CEPZ, Chittagong.

Types of machines used for washing which are shown below in Figure 1, Figure 2 and Figure 3.

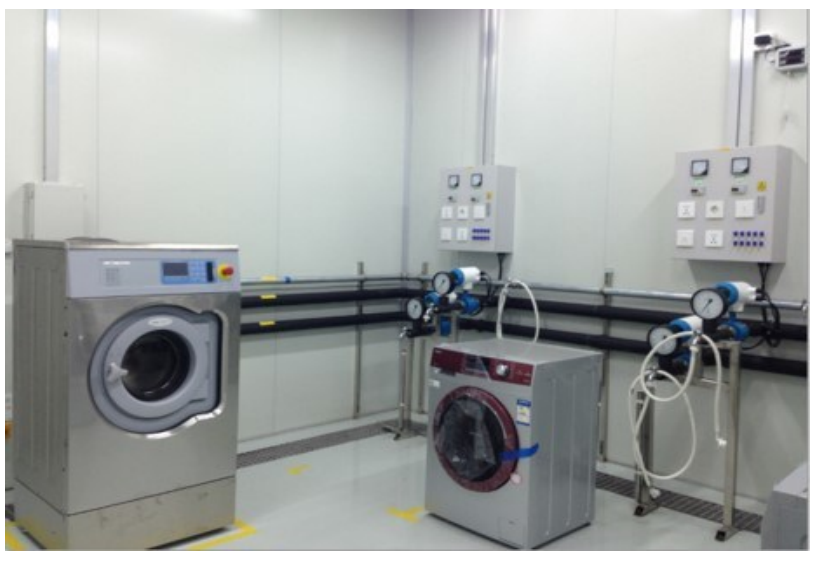

Figure 1. Washing Machine.

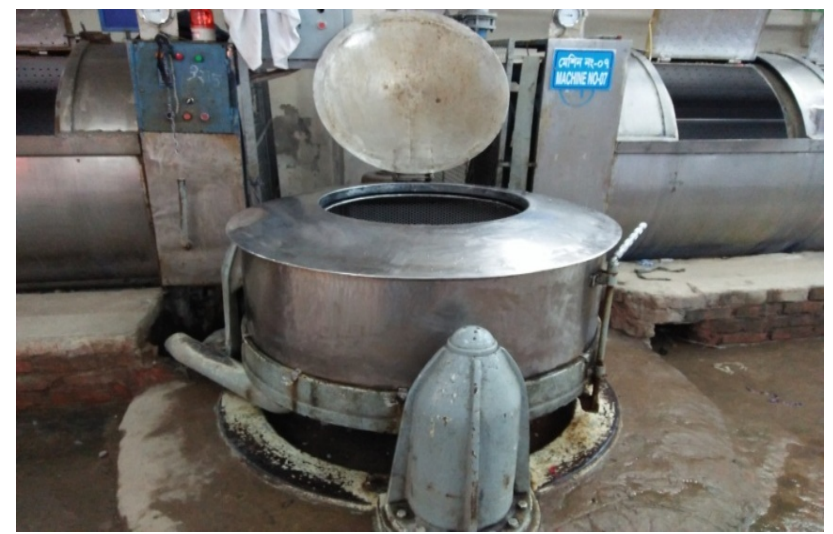

Figure 2. Hydro Extractor.

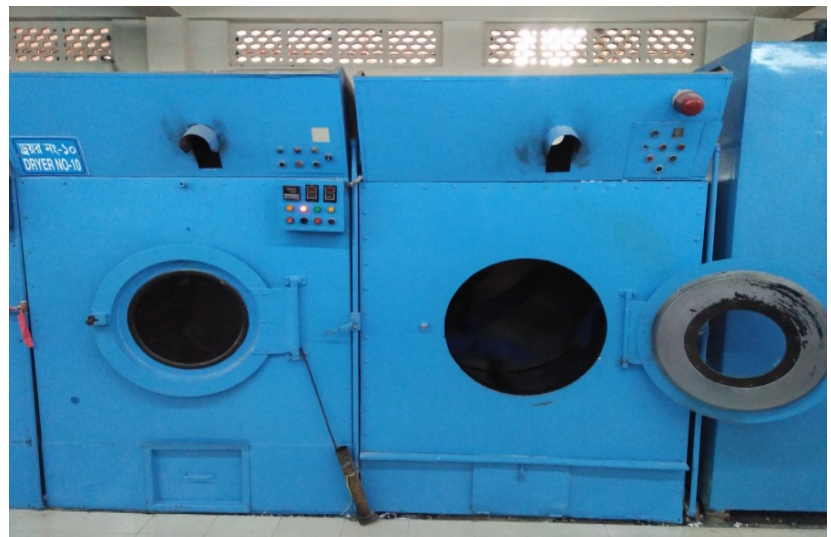

Figure 3. Dryer. 
2.2.1. Sample Washing Machine Specification:

Name of the machine: Washing machine;

Brand: Mathis;

Origin: Switzerland;

Model: GW-5;

Serial No: 140472;

Rated Power: 3W-380V;

Weight: $55 \mathrm{Kg}$.

\subsubsection{Dryer}

Specification:

Name of the machine: Dryer machine;

Brand: SIEMENS;

Origin: China;

Model: WD12D523.

\subsection{Machine Used for Testing Which Is Shown Below in (Figures 4-7)}

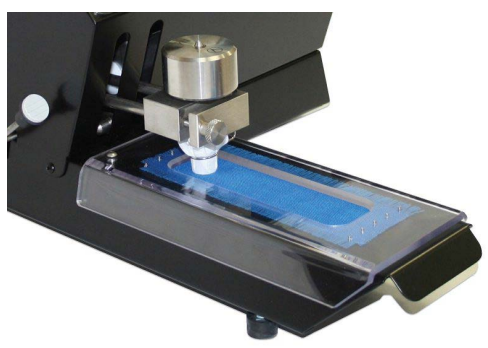

Crock Meter

Specification:

Brand: GESTER;

Model NO.: GT-D05;

Origin: China.

Figure 4. Crock Meter

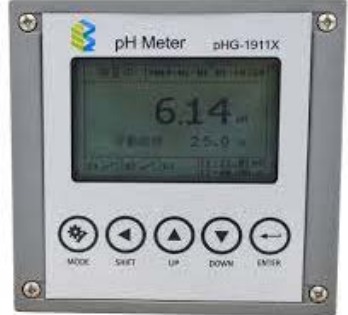

ph Meter

Specification:

Brand: EIT;

Model NO.: pHG-1911X;

Origin: New Zealand.

Figure 5. ph Meter. 


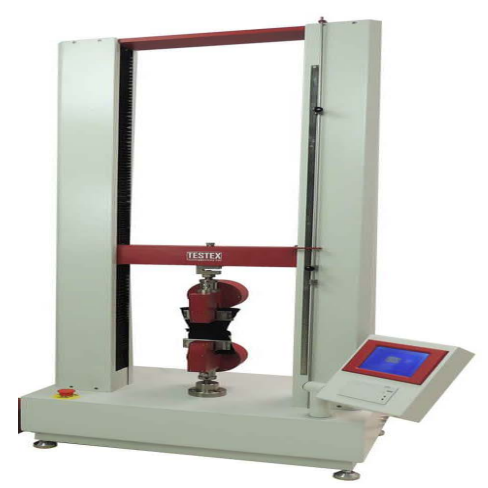

Tensile Strength Tester

Specification:

Brand: TESTEX;

Model NO.: TF002;

Origin: China.

Figure 6. Tensile Strength Tester.

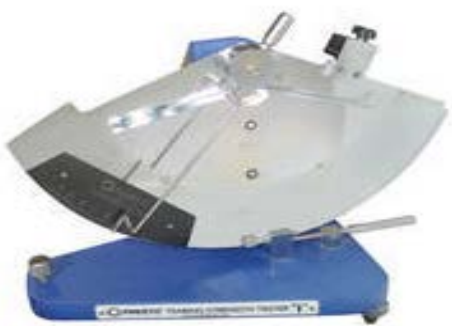

Tear tester

Specification:

Brand: TESTEX;

Model NO.: TF-140A;

Origin: Chaina.

Figure 7. Tear tester.

\subsection{Stone Enzyme Wash}

A Leg panel was taken for this experiment which is 200 gram. At first, the leg panel was taken for desizing treatment then Stone enzyme wash is done. After washing and drying, various test is done. The process parameters are given below.

\subsubsection{The Process of Stone Enzyme Wash}

\section{Desizing}

Fabric weight: $0.2 \mathrm{~kg}$;

Water: 1.8 liters;

Temperature: $50^{\circ} \mathrm{C}$;

Desizing agent: $1.08 \mathrm{gm}$;

Anti-Back staining agent: $1.8 \mathrm{gm}$;

Time: $15 \mathrm{~min}$.

Stone enzyme wash

Water: 1.6 liters; 
Pumice stone: $0.1 \mathrm{~kg}$;

Temperature: $45^{\circ} \mathrm{C}$;

Neutral Enzyme: $2.7 \mathrm{gm}$;

Anti-Back staining agent: $1.44 \mathrm{gm}$;

Acetic Acid: 1.08 gm;

Time: 15 minutes.

Bleach wash

Water: 1.6 liters;

Bleaching agent: $\mathrm{KMnO}_{4}(18 \mathrm{gm})$;

Temperature: $60^{\circ} \mathrm{C}$;

Time: 10min;

Neutralization;

Sodium Hyposulphite (5.4 gm) is used for neutralizing.

Hydro extraction

Hydro-extraction is done for $1.5 \mathrm{~min}$ to extract all the excess water from the fabric.

Dryer

Steam drier is used to dry the fabric. Machine is run for 20 minutes.

\subsubsection{Flowchart for the Whole Process}

\section{1) Desizing}

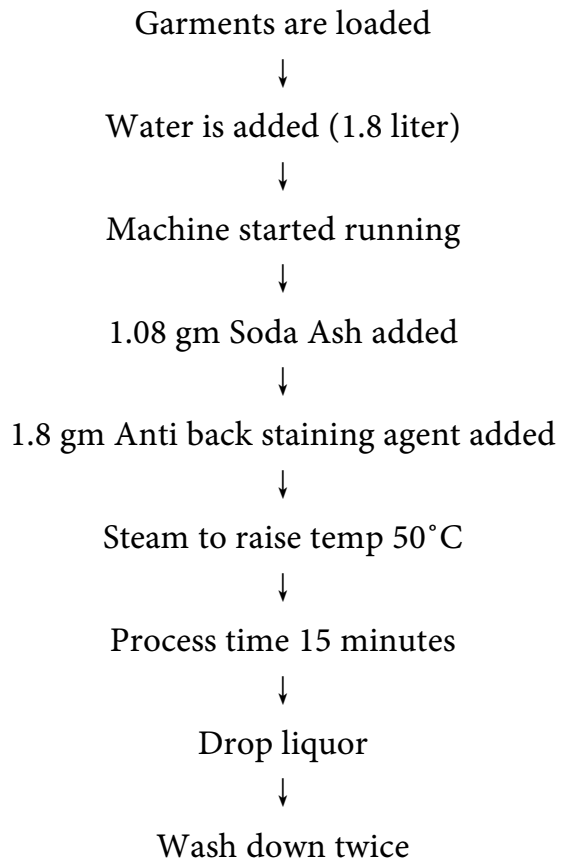

2) Stone Enzyme wash

Garments loading

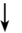

Water is added (1.6 Liter) 


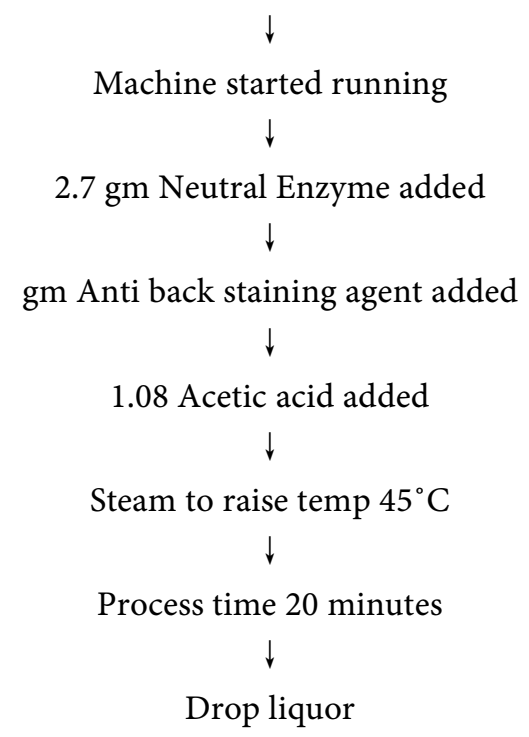

3) Bleach wash

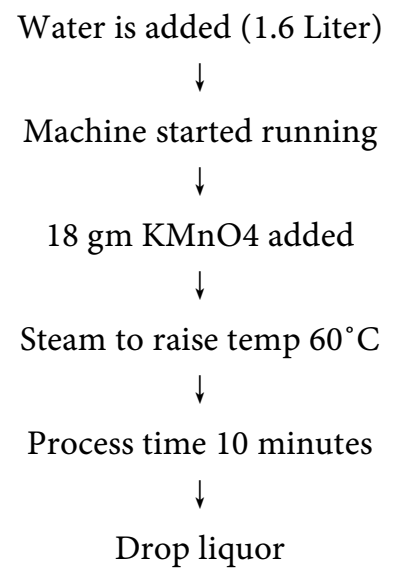

4) Neutralization

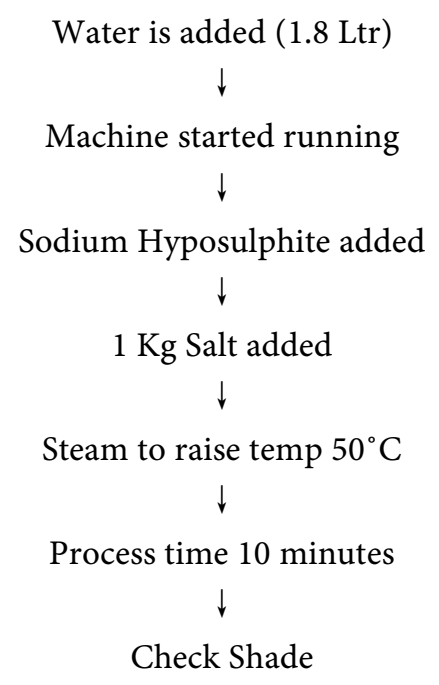


Drop the liquor

\title{
5) Drying
}

\author{
Garments are then taken out \\ Hydro extracted for $1.5 \mathrm{~min}$ \\ Send to dryer for 20 minutes
}

\subsection{Method of Acid Wash}

A Leg panel was taken for this experiment which is 200 gram. At first, the leg panel was taken for desizing treatment then stone wash and acid wash is done. After washing and drying, various test is done. The process parameters are given below.

\section{Process of Acid Wash}

Desizing

Fabric weight: $0.2 \mathrm{~kg}$;

Water: 2 liters;

Temperature: $60^{\circ} \mathrm{C}$;

Desizing agent: $2 \mathrm{gm}$;

Anti-Back staining agent: 2 gm;

Time: $20 \mathrm{~min}$.

Stone wash

Water: 1.6 liters;

Temperature: $25^{\circ} \mathrm{C}$;

Metabisulphate: $8 \mathrm{gm}$;

Time: 5 min.

\section{Acid Wash}

Water: 0.26 ltr;

Acetic Acid: 26 gm;

potassium permanganate: $6.5 \mathrm{gm}$;

Thermocol balls are put into the washing machine;

Temperature: 25;

Time: 10 min.

After two rinse wash we do the neutralization process with sodium Meta bi sulfite. Then treated denim leg panels were rinsed two times.

\section{Neutralization}

Water: 1.6 liters;

Temperature: $25^{\circ} \mathrm{C}$;

Metabisulphate: $8 \mathrm{gm}$;

Time: 5 min.

\section{Softener}


Water: 1.4 liters;

Temperature: $25^{\circ} \mathrm{C}$;

Acetic Acid: $0.84 \mathrm{gm}$;

Softener: $1.4 \mathrm{gm}$;

Time: $5 \mathrm{~min}$.

Hydro Extracting and Drying Processes

Extracting and Drying

Process flowchart of Acid Wash

Loading
$\downarrow$
Desizing (If Necessary)
$\downarrow$
Conditioning of the garments
$\downarrow$
Stone Preparation
$\downarrow$
Acid Wash
$\downarrow$
Neutralization Of By-product (MNO2)
$\downarrow$
Neutralization
$\downarrow$
Finishing/Softening
$\downarrow$
Drying.

\subsection{Method of Testing}

\subsubsection{Shrinkage}

A square of $10^{\prime \prime} \times 10^{\prime \prime}$ is marked on the fabric samples using permanent marker before washing.

The length and width of the square are measured after washing.

\subsubsection{Tearing Strength}

Denim Fabric;

Knife;

Tear template;

Tear tester.

\subsubsection{Rubbing Test}

L-Histidine hydrochloride monohydrate: $0.5 \mathrm{~g} / \mathrm{L}$;

Di-sodium hydrogen orthophosphate di hydrate: $2.7 \mathrm{~g} / \mathrm{L}$;

Sodium chloride: $5 \mathrm{~g} / \mathrm{L}$;

Time: 4 hrs;

Temp: $37^{\circ} \mathrm{C}$. 


\subsubsection{Color Fastness to Wash}

Sample dimensions- 6" $\times 2$ ".

Washing parameters:

Temperature: $49^{\circ} \mathrm{C}$;

Time: 45 min;

RPM: 40;

Steel Ball: 50 pcs;

Dia of steel ball: $6 \mathrm{~mm}$.

\subsection{5. pH Test}

Machine used-Mettler Toledo $\mathrm{pH}$ meter.

$250 \mathrm{ml}$ distilled water taken and boiled for 10 minutes. Then $10 \mathrm{gm}$ sample is cut in small pieces in 2 batches and added to the water one batch at a time and kept under water for 10 minutes. The temperature has to be moderate and the sample is cooled after taking out of the water.

\section{Results and Discussion}

\subsection{Results}

Shrinkage percentage test report which is shown below in Table 1.

Tearing Strength Test report which is shown below in Table 2.

Colorfastness to Rubbing Test report which is shown below in Table 3.

Colorfastness to wash test report which is shown below in Table 4 .

$\mathrm{pH}$ test report which is shown below in Table 5 .

Table 1. Test report for shrinkage percentage.

\begin{tabular}{ccc}
\hline \multirow{2}{*}{ Wash type } & \multicolumn{2}{c}{ Shrinkage percentage } \\
\cline { 2 - 3 } & Length wise & Width wise \\
\hline Stone enzyme wash & $8 \%$ & $10 \%$ \\
Acid wash & $4 \%$ & $5 \%$ \\
\hline
\end{tabular}

Table 2. Test report for Tearing Strength Test.

\begin{tabular}{ccc}
\hline \multirow{2}{*}{ Wash type } & \multicolumn{2}{c}{ Tearing Strength Test } \\
\cline { 2 - 3 } & Warp & Weft \\
\hline Stone enzyme wash & 49.6 & 24.6 \\
Acid wash & 56.4 & 29.2
\end{tabular}

Table 3. Test report for colorfastness to rubbing

\begin{tabular}{|c|c|c|c|c|}
\hline \multirow{3}{*}{ Wash type } & \multicolumn{4}{|c|}{ Assessments } \\
\hline & \multicolumn{2}{|c|}{ Grade for changing } & \multicolumn{2}{|c|}{ Grade for staining } \\
\hline & Dry & Wet & Dry & Wet \\
\hline Stone enzyme wash & $4 / 5$ & 2 & $4 / 5$ & 2 \\
\hline Acid wash & $3 / 4$ & $1 / 2$ & $3 / 4$ & $1 / 2$ \\
\hline
\end{tabular}




\subsection{Discussion}

\subsubsection{Shrinkage}

From the shrinkage test done on $10 " \times 10^{\prime \prime}$ sample, it found out both lengthwise and widthwise shrinkage occurred in the fabric. But the stone enzyme wash shrinkage percentage is higher than the acid wash which is shown below in Figure 8.

\subsubsection{Rubbing Test}

Here the crock meter is used to test the rubbing fastness on the fabric in both dry and wet condition. During stone enzyme wash color fastness of rubbing very good in dry condition and fairly good in wet condition. During acid wash color

Table 4. Test report for colorfastness to wash.

\begin{tabular}{cccccccc}
\hline \multirow{2}{*}{ Wash type } & \begin{tabular}{c} 
Grade \\
\cline { 3 - 7 }
\end{tabular} & \multicolumn{5}{c}{ Color staining to multi-fibre fabric } \\
\cline { 2 - 7 } & for changing & Acetate & Cotton Nylon Polyester & Acrylic Wool \\
\hline Stone enzyme wash & $4 / 5$ & 0 & 4 & 4 & 0 & 0 & 0 \\
Acid wash & $4 / 5$ & 0 & $4 / 5$ & $4 / 5$ & 0 & 0 & 0 \\
\hline
\end{tabular}

Table 5. Test report for $\mathrm{pH}$.

\begin{tabular}{cc}
\hline Wash type & $\mathrm{pH}$ \\
\hline Stone enzyme wash & 5.2 \\
Acid wash & 5.8 \\
\hline
\end{tabular}

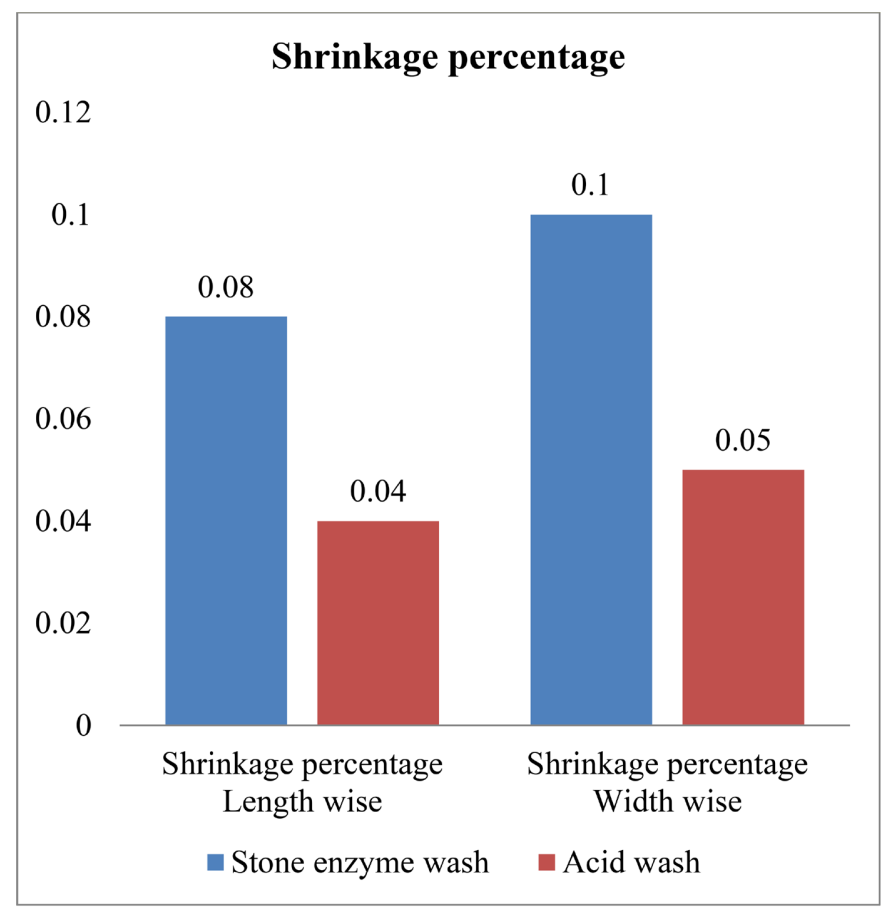

Figure 8. Graphical comparison for shrinkage percentages of both washes. 
fastness of rubbing fairly good in dry condition and very poor in wet condition which are shown below in Figure 9.

\subsubsection{Tearing Strength Test}

Here checked both the warp way strength and weft way strength after wash. In warp way and weft way strength, acid wash sample higher than stone enzyme wash sample strength which are shown below in Figure 10.

\subsubsection{Color Fastness to Wash}

After washing the leg panel under laboratory condition, we used the gray scale to measure the color fastness to wash where it scored 4.5 for stone enzyme and 4 for acid wash that means stone enzyme sample is very good and acid wash sample is good. That means, after both washing the leg panel shows considerable performance to color fastness to wash which are shown below in Figure 11.

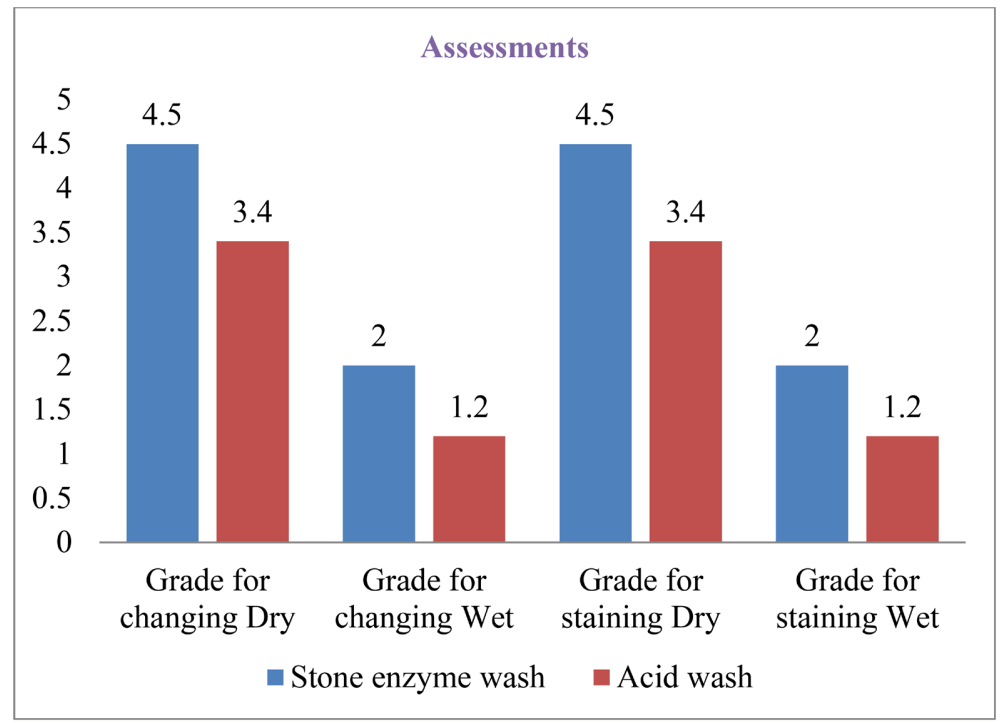

Figure 9. Graphical comparison for rubbing percentages of both washes.

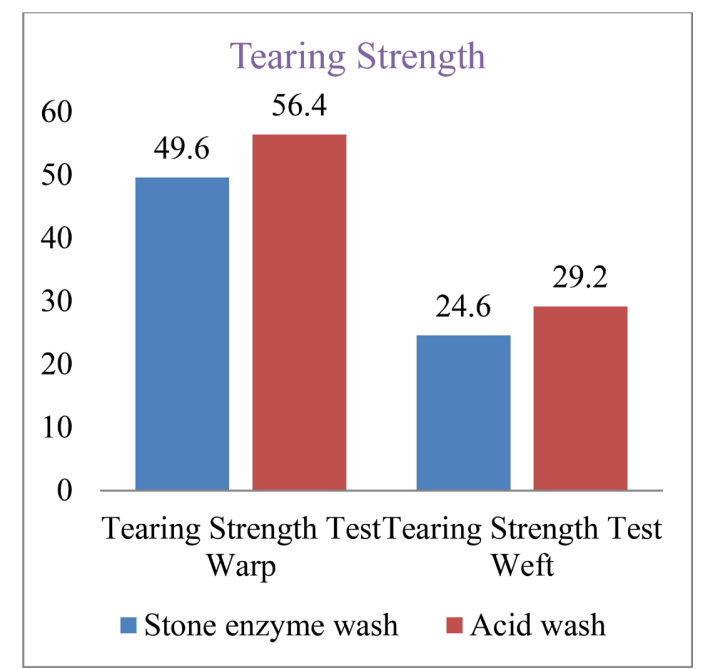

Figure 10. Graphical comparison for tearing strength of both washes. 


\subsection{5. pH Test}

We checked the $\mathrm{pH}$ of the leg panel surface using the $\mathrm{pH}$ meter and the result was slightly different for the two washes. But the variation was 0.6 and in both cases the fabric was slightly acidic at 2.2 and 2.8, which are shown below in Figure 12 .

\section{Conclusions}

The aim of this project is to observe the impact of stone enzyme wash and acid wash on denim apparel characteristics. For that purpose, three same denim fabrics with twill $3 / 1$ construction are made and after washing, changes in the characteristic of denim fabric have been observed. All washing treatments indicated

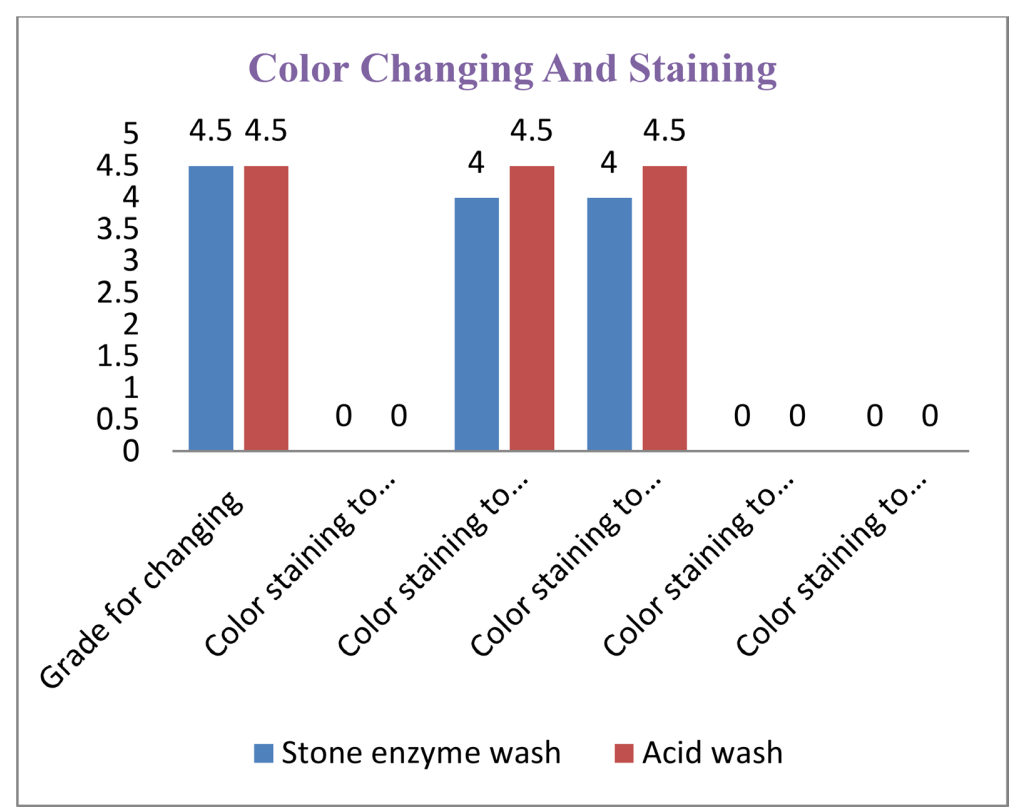

Figure 11. Graphical comparison for color changes of both washes.

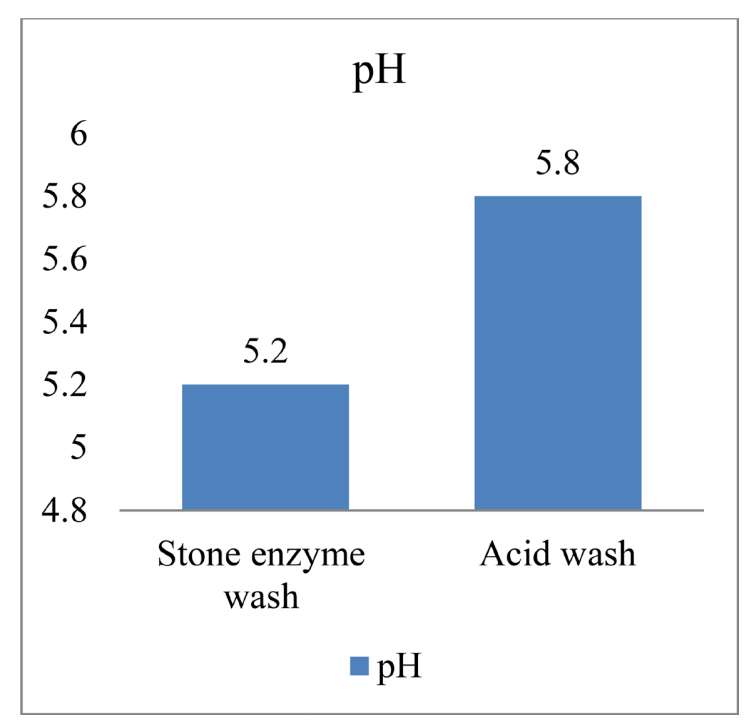

Figure 12. Graphical comparison for $\mathrm{pH}$ of both washes. 
great influence on the tear strength, weight loss of fabric because of the variation of chemical, washing process, time, temperature and fabric.

Finally, in denim washing our country has a bright future due to wide spread market of denim garments. We need thorough knowledge of denim treatment process and also of the fashion going around the world. And this project will be a guideline for those who are interested in this sector. We believe that this project will be a guideline for the washing plants in understanding and doing various treatments.

In this paper, the impact of Stone Enzyme wash and Acid wash is observed. From this study, it is found that by the treatment of stone enzyme and acid the constructions of the garments are not changed a lot except GSM. On the other hand, although strength of the garments is reduced, it is within the acceptable range. Shrinkage of the garments does not exceed the required level after treatment. So stone enzyme and acid washing produce moderately aged looks of the garments as well as comfort.

\section{Conflicts of Interest}

The authors declare no conflicts of interest regarding the publication of this paper.

\section{References}

[1] Vehmas, K., et al. (2018) Consumer Attitudes and Communication in Circular Fashion. Journal of Fashion Marketing and Management, 22, 286-300. https://doi.org/10.1108/JFMM-08-2017-0079

[2] Vieira, V.A. (2009) An Extended Theoretical Model of Fashion Clothing Involvement. Journal of Fashion Marketing and Management, 13, 179-200. https://doi.org/10.1108/13612020910957707

[3] Dangel, U. (2016) Turning Point in Timber Construction: A New Economy. Birkhäuser, Basel, Switzerland. https://doi.org/10.1515/9783035608632

[4] Miah, M.S., et al. (2015) A Comparative Study on the Effect of Liquor Ratio of Acid and Neutral (Powder) Enzyme on Denim Garments. European Scientific Journal, 11, 245-252.

[5] Choudhury, A.K.R. (2017) Environmental Impacts of Denim Washing. In: Muthu, S.S., Ed., Sustainability in Denim, Woodhead Publishing, Sawston, Cambridge, 49-81. https://doi.org/10.1016/B978-0-08-102043-2.00003-4

[6] Kan, C.W. (2015) Washing Techniques for Denim Jeans. In: Paul, R., Ed., Denim, Woodhead Publishing, Sawston, Cambridge, 313-356. https://doi.org/10.1016/B978-0-85709-843-6.00011-1

[7] Elahi, S., et al. (2019) Analysis of Physical \& Chemical Properties of Cotton-Jute Blended Denim after a Sustainable (Industrial Stone Enzyme) Wash. Journal of Textile Science and Fashion Technology, 3, 1-8. https://doi.org/10.33552/JTSFT.2019.03.000558

[8] Mahmud, M. and Islam, M. (2018) Study on Different types of wash effect on denim garments. Daffodil International University, Dhaka, Bangladesh.

[9] Islam, M. and Hossain, M. (2018) Industrial Attachment at Standard Group Ltd. 
Daffodil International University, Dhaka, Bangladesh.

[10] Solaiman, Rouf, A., Rasel, S. and Khalil, E. (2015) Investigation of Different Washing Effects on Physical and Mechanical Properties of Cotton Knitted Garments. Journal of Textile Science and Technology, 1, 101-109.

[11] Feinberg, J. (2014) Rights, Justice, and the Bounds of Liberty. Princeton University Press, Princeton, New Jersey. https://doi.org/10.4236/jtst.2015.13011 